\title{
Anal Cancer pN0 TNM Finding v6 and v7
}

National Cancer Institute

\section{Source}

National Cancer Institute. Anal Cancer pNO TNM Finding v6 and v7. NCI Thesaurus. Code C67544.

Anal cancer with no evidence of metastasis to regional lymph nodes. (from AJCC 6th and 7th Eds.) 